COMMENTARY ON COVID-19 AND THE FoOd SyStem

\title{
Food supply pressure in France and Germany during COVID-19: Causes from manufacturing
}

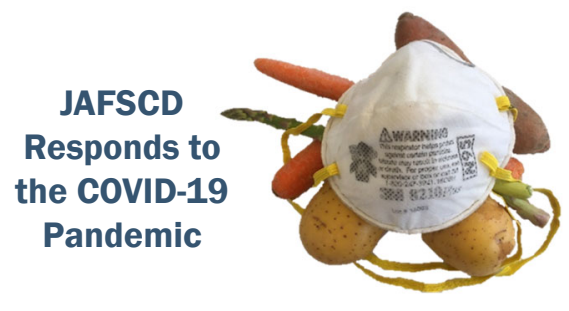

\author{
Suyu Liu * \\ Vienna, Austria
}

Submitted June 8, 2020 / Published online June 19, 2020

Citation: Liu, S. (2020). Food supply pressure in France and Germany during COVID-19:

Causes from manufacturing. Journal of Agriculture, Food Systems, and Community Development, 9(4), 139-142. https://doi.org/10.5304/jafscd.2020.094.007

Copyright (C 2020 by the Author. Published by the Lyson Center for Civic Agriculture and Food Systems. Open access under CC-BY license.

$T^{1}$ he food supply has been disrupted by COVID-19. Shopping in supermarkets and grocery stores in the pandemic may not be a pleasant experience, as it can often lead to disappointment and anxiety since a lot of food items are not available or out of stock. The pandemic's impact on the food supply has attracted attention from scholars and practitioners alike, and there have been many studies based on evidence from developing countries (e.g., Zurayk, 2020). However, there is still a lack of research based on the experiences of more developed and industrialized economies such as France and Germany. This is an important knowledge gap to be bridged, as people in developed countries tend to consume more food than those in developing countries (Delgado, 2003). Developed countries are also usually in the center of global food supply chains due to their stronger influence in trade.

Little has been discovered in particular regarding the reasons for the food supply crisis in developed high-income countries, especially France and Germany. It is beyond popular belief and the existing academic knowledge to notice that France and Germany, the two largest economies with the most developed agriculture and the highest income levels in the European Union (EU), have experienced a shock to their food supplies since March 2020. Especially in the early period of the COVID-19 outbreak in these two countries, the shortage of the food supply became a major challenge to people's daily lives

* Suyu Liu, Vienna, Austria; suyu.liu@linacre.ox.ac.uk

\section{Acknowledgments}

The author is grateful for insights from former peers and colleagues at University of Oxford and United Nations Industrial Development Organization (UNIDO). The views in this commentary are solely the author's and do not reflect any official stance of any academic institute and/or the United Nations and subordinate organizations, including UNIDO. 
and normal business operation. For example, it was difficult for households to buy sufficient preserved food and long-life milk from the supermarkets and grocery stores they usually visit, and shops had to set quotas on customers' purchasing of many products. The situation seemed to improve after strong measures were taken to restore the food supply in France and Germany. For example, food delivery has been an approved exception to the governmental travel restrictions during the pandemic. Nevertheless, varieties of food and drinks were still in short supply or out of stock during the pandemic, especially at the early stage, as shown in Photos 1 and 2. Therefore, the reasons for the food supply crisis in France and Germany are worth exploring.

\section{Photos 1 and 2. Empty Supermarket Food Stock in France and Germany}
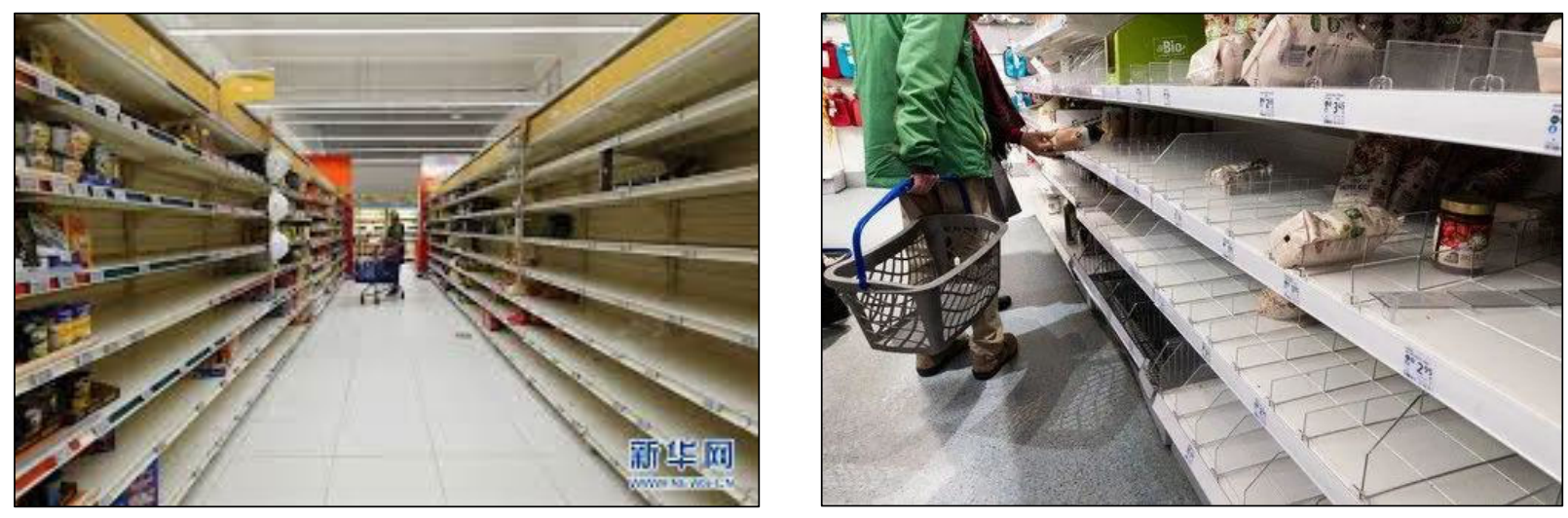

Source: Xinhua News (2020a, 2020b). Note: Picture 2 has been cross-posted via WeChat.

Although the panic from the COVID-19 pandemic is perceived as a catalyst for the pressure on the food supply, there could be other interpretations. As noted by the Food and Agriculture Organization of the United Nations (FAO, 2020), COVID-19's disruption to agriculture is minimal, and the food market is largely stable. Furthermore, in France and Germany, technology is widely applied in the agriculture sector, and therefore COVID-19 is unlikely to have significant impact on the countries' agricultural activities, which are not highly labor-intensive. In addition, media have reported that excessive amounts of milk have been produced and producers have to reduce the milk supply in France and Germany (Stöcker, 2020), but in the supermarket milk is often sold out.

Therefore, in France and Germany, if the sudden increase in demand is not the only reason for the strain on food supply, and COVID-19's impact on agricultural activities is minimal, what could be the other reasons? A less mentioned yet important reason is the shrinking of manufacturing, and particularly of a few sub industries closely related to food production and delivery.

Data from the United Nations Industrial Development Organization (UNIDO) provides evidence to support this argument. As shown in Table 1, the manufacturing of food products in both France and Germany dropped in March 2020. Specifically, in France, manufacturing of food products fell by 2.3\%, compared to February 2020. Similarly, Germany observed a reduction (-4.1\%) in manufacturing of food products in March 2020 compared to March 2019. Since the sub-industry 'manufacturing of food products' mainly includes the 'processing and preservation' of food and dairy products (United Nations Statistics Division, 2008), it is not difficult to explain why long-life milk and preserved foods were quickly sold out in supermarkets in France and Germany. The shrinking of beverage manufacturing was much more notable in France than in Germany. In short, the reduction in manufacturing of food and beverages (industries with low technology intensity that were therefore more significantly affected by COVID19) (UNIDO, 2019) is fueling the pressure on the food supply in France and Germany. 
Table 1. Manufacturing Production in France and Germany, March 2020

\begin{tabular}{|c|c|c|c|c|}
\hline Country & Manufacturing sub-industries & $\begin{array}{l}\text { Index of Industrial } \\
\text { Production } \\
(2015=100)\end{array}$ & $\begin{array}{l}\text { Compared to } \\
\text { previous month }\end{array}$ & $\begin{array}{l}\text { Compared to same } \\
\text { month previous year }\end{array}$ \\
\hline \multirow{4}{*}{ France } & Manufacture of food products & 97 & $-2.3 \%$ & $-0.3 \%$ \\
\hline & Manufacture of beverages & 86.6 & $-12.7 \%$ & $-15.8 \%$ \\
\hline & $\begin{array}{l}\text { Manufacture of motor vehicles, trailers, and } \\
\text { semi-trailers }\end{array}$ & 52.1 & $-49.1 \%$ & $-54.4 \%$ \\
\hline & Total manufacturing & 85 & $-18.3 \%$ & $-19.3 \%$ \\
\hline \multirow{4}{*}{ Germany } & Manufacture of food products & 99.8 & $-1.1 \%$ & $-4.1 \%$ \\
\hline & Manufacture of beverages & 101.2 & $-6.6 \%$ & $0.9 \%$ \\
\hline & $\begin{array}{l}\text { Manufacture of motor vehicles, trailers, and } \\
\text { semi-trailers }\end{array}$ & 60.7 & $-31.1 \%$ & $-37.7 \%$ \\
\hline & Total manufacturing & 89.5 & $-11.5 \%$ & $-14.5 \%$ \\
\hline
\end{tabular}

Source: UNIDO, 2020.

Another reason for the strain on the food supply is the sharp decrease in the manufacturing of motor vehicles, trailers, and semi-trailers (MTS). MTS manufacturing is noteworthy because these vehicles are the most widely used tools to deliver food products from producers to customers, including intermediary customers such as supermarkets and grocery stores. Although it is sometimes perceived that the existing fleets of MTS may be sufficient to satisfy the needs under normal circumstances, this is not the case during the pandemic. The demand for delivery services using MTS increased sharply amid COVID-19 health concerns (Kendall, 2020), which may lead to longer-running shifts and higher frequency of MTS use. Hence there will be more depreciation, scrapping (writing-off), and repairing of MTS, which reduces the availability of MTS to meet the soaring demand of food delivery services. As the pandemic effectively shuttered the manufacturing of MTS, Europe's freight market is predicted to shrink significantly (van Marle, 2020), especially in the delivery of food products. This has been exacerbated by the 'just in time' manufacturing model that has emerged in recent years and the fact that many companies do not keep extra resources for unexpected disturbances (Bloom, 2020). That is why refrigerated vehicles used for storing dead bodies during the pandemic have been reused for food delivery (Crump, 2020). Fleets of supply trucks owned by some business closed in the pandemic are also to be used for food delivery (Bloom, 2020).

Table 1 shows that in France, the manufacturing of MTS dropped by over 50\% in March 2020 compared with the same period in 2019. The decrease of MTS manufacturing in Germany is also substantial $(-37.7 \%)$. A sudden and significant reduction of the MTS manufacturing would strain to food supply chains. This explains an aforementioned imbalance, where the production of food and beverages has been excessive, but such a huge supply cannot be transported to the market due to the lack of MTS. Therefore food and beverages are easily sold out in the supermarkets and grocery stores. This lack of MTS is also an important factor in the long wait times for online food delivery in France and Germany (Reimann, 2020).

This brief commentary demonstrates that the reduction in manufacturing production, especially that of food, beverages, and MTS, is an important reason for the pressure on the food supply chain in France and Germany during the pandemic. This commentary also has a few implications. The examination of the food supply should not be restricted to agriculture and service sectors; and it should also be extended 
to manufacturing, which plays a critical role in the food supply chain. This commentary therefore calls for more interdisciplinary inquiries. In addition, more research on the food supply in developed countries during the pandemic could enrich the knowledge of how COVID-19 affects the food system.

\section{References}

Bloom, J. (2020, March 26). How are food supply networks coping with coronavirus? BBC News. Retrieved from https://www.bbc.co.uk/news/business-52020648

Crump, J. (2020, May 14). Refrigerated trucks used to store bodies during coronavirus can go back to hauling food, FDA says. Independent. Retrieved from https://www.independent.co.uk/news/world/americas/coronavirus-fdarefrigerated-trucks-dead-bodies-food-a9515421.html

Delgado, C. L. (2003). Rising consumption of meat and milk in developing countries has created a new food revolution. The Journal of Nutrition, 133(11), 3907S-3910S. https://doi.org/10.1093/in/133.11.3907S

FAO. (2020). Q\&A: COVID-19 pandemic - impact on food and agriculture security. Retrieved from the Food and Agriculture Organization of the United Nations website: http://www.fao.org/2019-ncov/q-and-a/impact-on-food-and-agriculture/en/

Kendall, E. (2020, April 18). Tesco delivery driver reveals all behind the scenes during coronavirus outbreak. SomersetLive. Retrieved from https://www.somersetlive.co.uk/news/somerset-news/supermarket-delivery-driver-somerset-coronavirus-4047743

Reimann, E. (2020, April 2). Plötzlich beliebt: Corona beflügelt Lebensmittel- Lieferdienste [Suddenly popular: Corona inspires food delivery services]. Absatzwirtschaft. Retrieved from https://www.absatzwirtschaft.de/ploetzlich-beliebt-corona-befluegelt-lebensmittel-lieferdienste-171226/

Stöcker, C. (2020, April 6). Molkereien haben zuviel Milch—was tun? [Dairies have too much milk—What to do?] Elite Magazine. Retrieved from https://www.elite-magazin.de/markt/molkereien-haben-zuviel-milch-was-tun-12894.html

United Nations Industrial Development Organization (UNIDO). (2019). Classification of manufacturing sectors by technological intensity (ISIC Revision 4). Retrieved from https://stat.unido.org/content/focus/classification-of-manufacturingsectors-by-technological-intensity- $\% 2528$ isic-revision-4\%2529

UNIDO. (2020). Impact of COVID-19 on manufacturing [Data file and code book]. Retrieved from https://stat.unido.org/COVID-19

United Nations Statistics Division. (2008). International standard industrial classification of all economic activities: Revision 4. United Nations. Retrieved from https://unstats.un.org/unsd/publication/seriesM/seriesm 4rev4e.pdf

van Marle, G. (2020, April 16). Covid-19 could shrink Europe's road freight market by $20 \%$ this year. The Load Star. Retrieved from https://theloadstar.com/covid-19-could-shrink-europes-road-freight-market-by-20-this-year/

Xinhua News. (2020a, March 8). World in a week. Xinbuanet. Retrieved from http://www.xinhuanet.com/world/2020-03/08/c 1125680854 16.htm

Xinhua News. (2020b, March 5). Straight shot: Germany in the pandemic: No face masks, non-stop classes, but flour and toilet paper are almost gone ... We Chat. Retrieved from https://mp.weixin.qq.com/s/018H7r33A-zjN9nPuGaQ g

Zurayk, R. (2020). Pandemic and food security: A view from the Global South. Journal of Agriculture, Food Systems, and Community Development, 9(3), 17-21. https://doi.org/10.5304/jafscd.2020.093.014 